\title{
Comparison Study for Physical Quality Performance and Body composition Between Elite-Normal Junior Swimmers.
}

\section{*Dr/ Khaled M. Abdelkarem}

\section{Abstract:}

The aim of the study was to assess the Body composition and fitness between elite and normal junior swimmers. Methods The data was collected from randomly selected $(100 \mathrm{mal})$ sport healthy swimmers in Egypt in 2019.The variables consist of 22 items during three testes "Swimming, Fitness and Physiological and Anthropometrical testes". Control value for each parameter was calculated as an average value mean and standard deviation $\pm \mathrm{SD}$. The level used for accepting significance was $* \mathrm{P}<0.05$ and $* * \mathrm{P}<0.001$ Results The relative changes were calculated for each subject, an individual mean value and skewness between elite swimmers and normal swimmers for all parameters. it was a different significant for elite swimmers in most of parameters vital capacity between elite and normal junior Swimmers for elite Swimmers $(\mathrm{P}=5.07)$ with a Correlation for $100 \mathrm{~m}$ freestyle $(0.4608-* *)$, in Body Mass $(\mathrm{P}=2.82)$ with a Correlation $(0.5726-* *)$, in Pull up $(\mathrm{P}=1.46)$, with a Correlation (0.232-*).vertical jump $\left(\mathrm{P}=2.86^{* *}\right)$ with a Correlation (0.2675-*). available test of $4 \times 50 \mathrm{~m} / 10 \mathrm{sec}\left(\mathrm{P}=5.57^{* *}\right)$ with a Correlation $\left(0.4583^{* *}\right) .400 \mathrm{~m}$ Run $\left(\mathrm{P}=3.71^{* *}\right)$ with a Correlation $\left(0.3275^{* *}\right) .10: 20$ Swim sprint $\left(\mathrm{P}=3.10^{* *}\right)$ with a Correlation $(0.4061 * *) .25: 50$ Swim sprint $\left(\mathrm{P}=7.78^{* *}\right)$ with a Correlation for $100 \mathrm{~m}$ freestyle $\left(0.6045^{* *}\right)$. Grab/Track Start $15 \mathrm{~m}(\mathrm{P}=2.41 *)$ with a Correlation $(0.3222 * *)$. Core Flexibility $(\mathrm{P}=4.12 * *)$ with a Correlation $(0.4343-* *)$. Core Flexibility $\left(\mathrm{P}=4.12^{* *}\right)$ with a Correlation (0.4343-**). Flexibility front Foot $(\mathrm{P}=2.74 * *)$ and $\operatorname{Agility}\left(\mathrm{P}=2.15^{*}\right)$ for the elite junior swimmers. Discussion. in Total and Specific Contribution Ratio: first Sprint (S), second Lead Body Mass (LBM), Third Reaction time (RT), fourth Core Flexibility (CF), fifth vital capacity (VC), sixth Shoulder Flexibility (SF).in a correlation for the $100 \mathrm{~m}$ freestyle time record. Conclusions. Common assessments of Body composition and specific physical fitness in elite swimmers explain more variance in competition performance than Normal swimmers, as well as for $100 \mathrm{~m}$ events. These findings highlight the need to empirically assess testing

"Faculty of Sport and physical Education Department of Exercise Science - Asyut Uni, Egypt. 
regimens and suggest new tests in physical fitness and Anthropometrical characteristics.

Keywords: Body composition, swimming fitness, 100 freestyle, junior Swimmers.

\section{Introduction}

Swimming is one of the most interesting areas for testing sports anthropologists, primarily because of the specific conditions of the environment and its influence, or the observed relationship between the form and its function. Characteristics of the material the swim bodies have a great influence on the level of manifestation of a whole range of specific characteristics swimmer. As one of the valid measures for the assessment of physical fitness and physicality (Krivokapic, D. (2007). In swimming, a multitude of physical, physiological, biomechanical and psychological parameters influence performance. While body composition is believed to be an important contributor to performance in swimming, with some coaches placing a strong emphasis on it during the training preparation phase, previous research is limited and inconclusive (Shephard, M. E (2014). Recently, interest in the composition of the human body has been significantly growing with emphasis on maintaining a good ratio of components such as fat mass and lean body mass including muscle mass and water. (McArdle, W.D.; Katch, F.I, 2014), (Malá, L.; Zahálka,2017)In physical fitness, body composition is used to describe the percentages of fat, bone, water and muscle in human bodies.[1] Because muscular tissue takes up less space in the body than fat tissue, body composition, as well as weight, determines leanness. (composition of the body 2016), (Body Composition Tests. 2015). In competitive sport the knowledge of body tissue proportions is essential to determine the morphological characteristics of an athlete. The opportunity for excellence in sport practice depends on this very information. (Hulmi, J.J. 2017). Body Composition and Athletes, it is said that "body fat, not weight" is the best measure of health and fitness; thus, body composition assessment should be an integral part of each athletes' physical fitness profile regardless of body weight. (Pallavi Dave2016) .Body composition is considered as an ideal parameter for fitness 
analysis and is acquiring much more significance in estimating the fitness levels among individuals in sports and those eager to sustain exceptional physical fitness. (Subhedar R, 2015). The primary objective of this research was to assess the impact of Body composition and specific fitness in record of 100 swimming between elite normal Junior swimmers. It was assumed that the primary objective of the experiment would be attained by answering the following questions: Will the body composition cause changes in record swimming and What is the significance of changes in physical fitness testes in comparison to the elite-normal Swimmer, that contribute in swim record. It is assumed that the knowing of body composition and specific physical fitness will induce beneficial changes in swim record.

Aim:

Our aim was to measure the effect of Contribute the Body composition and specific physical fitness, on the short distance swimming as $100 \mathrm{~m}$ freestyle swim record.

\section{Material and Methods Subjects}

100 healthy swimmers junior sport volunteered for the study in (January 2019) Group (A) Elite Swimmers Group (B) Normal Swimmers. subject were $13.36 \pm 1.07$ years of age, height $157.77 \pm 10.14 \mathrm{~m}$ and weight $47.36 \pm 9.97 \mathrm{~kg}$. The subjects have at least $6.32 \pm$ 2.36 experience record in Swimming all subjects trained on Swim America program in short distance swimming pools. All subjects were clinically healthy and had no history of recent infection disease, asthma or cardiorespiratory disorders. Onward, all of them gave their written consent and the local ethics committee approved the study protocol. All subjects were assessed for the anthropometric measures required for the calculation of body composition variables (Matiegka, 1921), (Masanovic, B. (2018).

\section{Protocol}

Swimming test: $4 \times 50 \mathrm{~m} / 10$ sec,400m Run,10:20 Swim sprint,25:50 Swim sprint, Grab/Track Start 15 m. Fitness tests :Pull up, vertical jump, shoulder Flexibility horizontal, shoulder Flexibility Vertical, Core Flexibility, Flexibility front Foot, Flexibility Back Foot, Flexibility Side Foot, 
Flexibility Side Foot, computers A control value for Flexibility Outside Foot, each parameter was calculated Agility, Coordination, Balance. as an average value mean and

Physiological

Anthropometrical

and

Absolute vital capacity,

Relative vital capacity, Percent of Body Fat, Body Mass, Lead Body Mass.

\section{Data analysis}

The data obtained in the research were processed using the application statistics program SPSS 20.0 adjusted for the use on personal standard deviation $\pm \mathrm{SD}$,

Skewness, a correlation, and Specific Contribution Ratio between two group and the characteristics from Physical fitness, Physiological and Anthropometrical and Swimming testes for elite Swimmers and normal Swimmers. The level used for accepting significance was $* \mathrm{P}<0.05$ and $* * \mathrm{P}<0.001$.

Table (1)

Characteristics of 90 subjects

\begin{tabular}{l|c|c|c}
\hline \multicolumn{1}{c|}{ Characteristics } & Means \pm SD & Mean & Skewness \\
\hline \hline Age $($ year) & $13.36 \pm 1.07$ & 13 & 0.08 \\
\hline Height $(\mathrm{cm})$ & $157.77 \pm 10.14$ & 157.25 & 0.14 \\
\hline Weight $(\mathrm{kg})$ & $47.36 \pm 9.97$ & 47 & 1.01 \\
\hline Experience (Year) & $6.32 \pm 2.36$ & 6 & 0.03 \\
\hline 100 m Freestyle Record(sec) & $67.84 \pm 6.01$ & 67 & 1.05 \\
\hline Absolute vital capacity(mml) & $2998.89 \pm$ & 2950 & 0.35 \\
& 605.5 & & \\
\hline $\begin{array}{l}\text { Relative vital capacity } \\
\text { (mml/kg) }\end{array}$ & $64.58 \pm 13.23$ & 63.62 & 0.69 \\
\hline Percent of Body Fat $(\%)$ & $26.56 \pm 6.35$ & 26 & 0.32 \\
\hline Body Mass(kg) & $12.71 \pm 4.41$ & 12.59 & 0.50 \\
\hline Lead Body Mass(kg) & $34.57 \pm 7.40$ & 33.410 & 1.10 \\
\hline \hline
\end{tabular}

Data are means $\pm S D, n=90$. Skewness between $(+3,-3)$. 


\section{Results}

Table (2)

Characteristics of Fitness, Physiological and Anthropometrical

\begin{tabular}{|c|c|c|c|c|c|}
\hline \multirow[t]{2}{*}{ No } & \multirow[t]{2}{*}{ Variables } & $\begin{array}{c}\text { Elite Swimmer } \\
\quad \mathrm{N}=\mathbf{2 0}\end{array}$ & $\begin{array}{c}\text { Normal } \\
\text { Swimmer } \\
\mathbf{N}=\mathbf{2 0}\end{array}$ & \multirow[t]{2}{*}{ T- test } & \multirow[t]{2}{*}{$\begin{array}{c}\text { Correlation } \\
100 \mathrm{~m} \\
\text { freestyle }\end{array}$} \\
\hline & & Means \pm SD & Means \pm SD & & \\
\hline 1 & $\begin{array}{l}\text { Absolute vital } \\
\text { capacity }(\mathrm{mml})\end{array}$ & $3452.38 \pm 539.09$ & $2659.09 \pm 487.61$ & $5.07 * *$ & $0.4608-* *$ \\
\hline 2 & $\begin{array}{lr}\text { Relative vital } \\
\text { capacity }(\mathrm{mml} / \mathrm{kg})\end{array}$ & $62.11 \pm 8.48$ & $65.17 \pm 14.64$ & 0.84 & 0.0862 \\
\hline 3 & $\begin{array}{l}\text { Percent of Body } \\
\text { Fat (\%) }\end{array}$ & $23.9 \pm 4.66$ & $27.54 \pm 5.61$ & $2.31 *$ & 0.179 \\
\hline 4 & Body Mass(kg) & $11.53 \pm 3.35$ & $13.31 \pm 3.03$ & $2.82 *$ & $0.5726-* *$ \\
\hline 5 & $\begin{array}{l}\text { Lead Body Mass } \\
(\mathrm{kg})\end{array}$ & $42.33 \pm 5.46$ & $29.64 \pm 4.53$ & $8.30 * *$ & $0.1853-$ \\
\hline 6 & Pull up (n) & $5.52 \pm 2.82$ & $4.22 \pm 2.991$ & 1.46 & $0.232-*$ \\
\hline 7 & $\begin{array}{ll}\text { vertical jump } \\
(\mathrm{cm})\end{array}$ & $42.47 \pm 5.63$ & $37.27 \pm 6.26$ & $2.86 * *$ & $0.2675-*$ \\
\hline 8 & $\begin{array}{lll}\begin{array}{l}4 \times 50 \mathrm{~m} \\
(\mathrm{sec})\end{array} & / 10 & \mathrm{sec} \\
\end{array}$ & $113.95 \pm 11.40$ & $161.81 \pm 20.35$ & $5.57 * *$ & $0.4583 * *$ \\
\hline 9 & 400m Run(sec) & $298 \pm 23.12$ & $327.59 \pm 28.78$ & $3.71 * *$ & $0.3275^{* *}$ \\
\hline 10 & $\begin{array}{ll}10: 20 & \text { Swim } \\
\text { sprint(sec) }\end{array}$ & $8.28 \pm 0.808$ & $9.56 \pm 1.75$ & $3.10 * *$ & $0.4061 * *$ \\
\hline 11 & $\begin{array}{l}25: 50 \quad \text { Swim } \\
\text { sprint (sec) }\end{array}$ & $27.95 \pm 1.20$ & $33.71 \pm 3.24$ & $7.78 * *$ & $0.6045^{* *}$ \\
\hline 12 & $\begin{array}{l}\text { Grab/Track Start } \\
15 \mathrm{~m}(\mathrm{sec})\end{array}$ & $8.82 \pm 0.805$ & $9.79 \pm 1.69$ & $2.41 *$ & $0.3222 * *$ \\
\hline 13 & $\begin{array}{l}\text { Shoulder } \\
\text { Flexibility } \\
\text { horizontal }(\mathrm{cm})\end{array}$ & $43.09 \pm 10.88$ & $44.27 \pm 11.16$ & 0.350 & 0.0307 \\
\hline 14 & $\begin{array}{l}\text { Shoulder } \\
\text { Flexibility } \\
\text { Vertical }(\mathrm{cm})\end{array}$ & $54.61 \pm 8.45$ & $50.31 \pm 11.80$ & 1.37 & $0.1696-$ \\
\hline 15 & $\begin{array}{ll}\begin{array}{l}\text { Core } \\
(\mathrm{cm})\end{array} & \text { Flexibility } \\
\end{array}$ & $72.61 \pm 7.36$ & $58.86 \pm 13.73$ & $4.12 * *$ & $0.4343-* *$ \\
\hline 16 & $\begin{array}{ll}\text { Flexibility front } \\
\text { Foot }(\mathrm{cm})\end{array}$ & $67.95 \pm 5.06$ & $58.85 \pm 14.39$ & $2.74 * *$ & 0.2992 \\
\hline 17 & $\begin{array}{l}\text { Flexibility } \text { Back } \\
\text { Foot }(\mathrm{cm})\end{array}$ & $28.47 \pm 3.62$ & $25.18 \pm 5.32$ & $2.36^{*}$ & $0.1418-$ \\
\hline
\end{tabular}




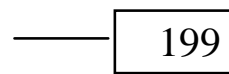

FollowTable (2)

Characteristics of Fitness, Physiological and Anthropometrical

\begin{tabular}{c|l|c|c|c|c}
\hline \hline No & \multicolumn{1}{|c|}{ Variables } & $\begin{array}{c}\text { Elite Swimmer } \\
\mathbf{N = 2 0}\end{array}$ & $\begin{array}{c}\text { Normal } \\
\text { Swimmer } \\
\mathbf{N = 2 0}\end{array}$ & $\begin{array}{c}\text { T- } \\
\text { test }\end{array}$ & $\begin{array}{c}\text { Correlation } \\
\mathbf{1 0 0} \mathbf{~ m} \\
\text { freestyle }\end{array}$ \\
\cline { 3 - 6 } & Means \pm SD & Means \pm SD & & 0.2139 \\
\hline \hline 18 & $\begin{array}{l}\text { Flexibility Side } \\
\text { Foot(cm) }\end{array}$ & $50.90 \pm 7.71$ & $54.81 \pm 10.58$ & 1.38 & 0.071 \\
\hline 19 & $\begin{array}{l}\text { Flexibility } \\
\text { Outside } \\
\text { Foot(cm) }\end{array}$ & $51.38 \pm 6.15$ & $52.90 \pm 7.64$ & 0.72 & 0.071 \\
\hline 20 & Agility(cm) & $11.68 \pm 0.56$ & $12.09 \pm 0.68$ & $2.15^{*}$ & 0.1714 \\
\hline 21 & $\begin{array}{l}\text { Coordination } \\
\text { (sec) }\end{array}$ & $5.50 \pm 0.707$ & $5.86 \pm 1.121$ & 1.25 & 0.1368 \\
\hline 22 & Balance(sec) & $10.14 \pm 5.24$ & $10.01 \pm 4.27$ & 0.09 & 0.0954 \\
\hline \hline
\end{tabular}

Data are means $\pm \mathrm{SD}, \mathrm{n}=90$ Significantly different from $* \mathrm{P}<0.05$, $* * \mathrm{p}<0.01$

Table (3)

Contribution Ratio Characteristics for Subject

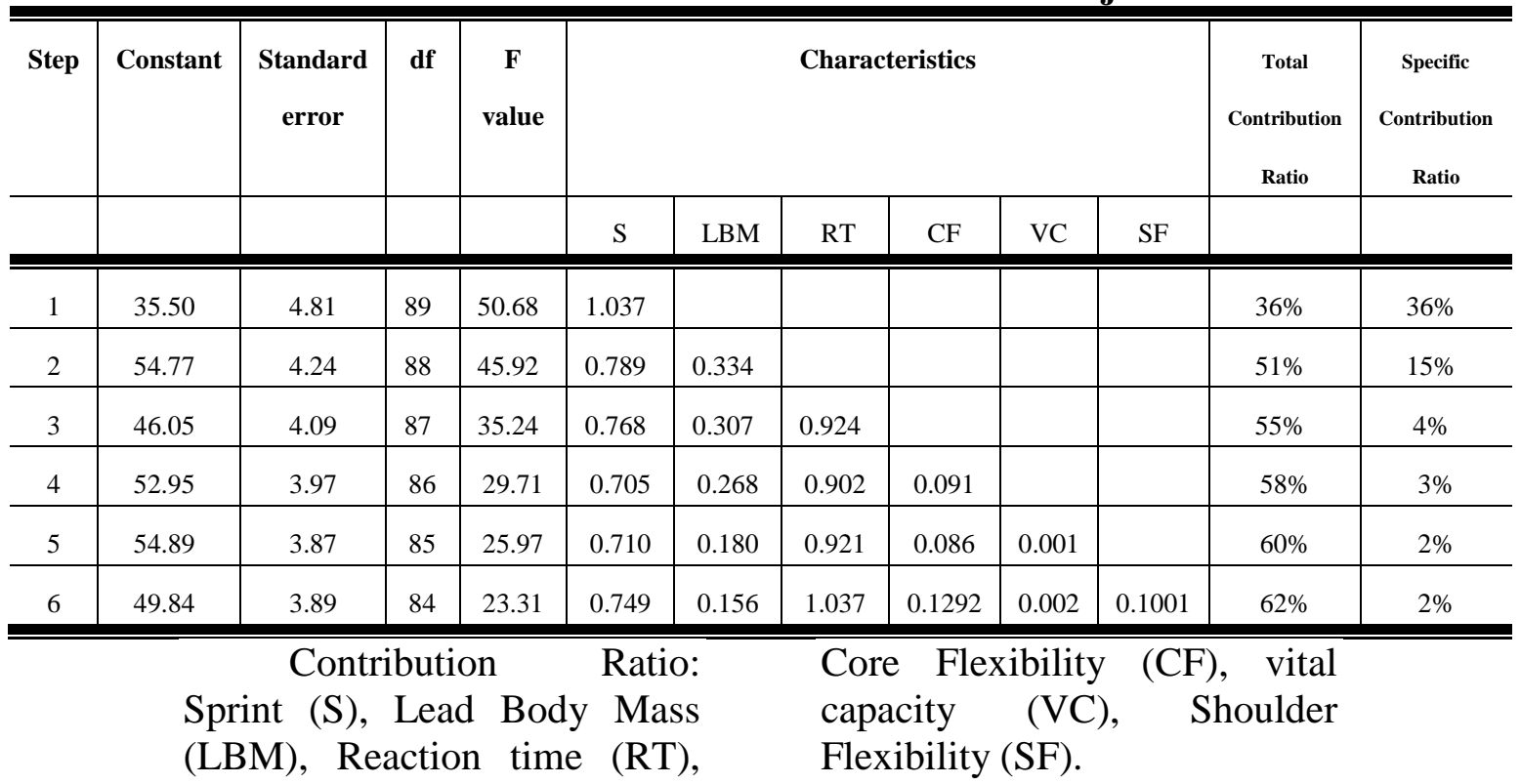




\section{0}

Fig.1. Contribution Ratio Characteristics for Subject

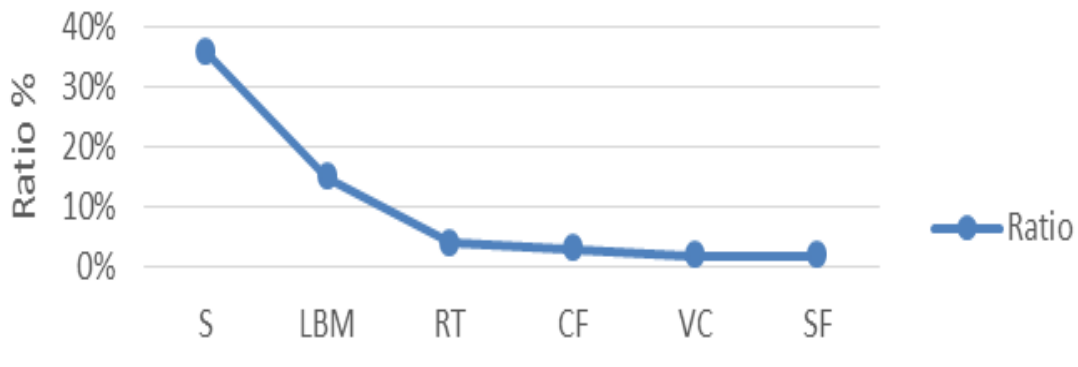

Characteristics

\section{Discussion}

According to the results of statistical analysis, Table (2) showed a significant difference in variable Absolute vital capacity between elite and normal junior Swimmers for elite Swimmers $(\mathrm{P}=5.07)$ with a significant Correlation for $100 \mathrm{~m}$ freestyle $(\mathrm{r}=0.4608-* *)$, Showed a significant difference in Body $\operatorname{Mass}(\mathrm{P}=2.82)$ with a Correlation for $100 \mathrm{~m}$ freestyle $(\mathrm{r}=0.5726-* *)$. importance of body composition in sport performance is a primary concern in creating athletes' profiles as well as conditioning programs throughout a season at all levels of competition (Silvestre et al., 2006), in that describing anthropometric characteristics and body compositions of athletes and detecting possible differences in relation to competition levels may give coaches a better working knowledge of the studied groups of athletes. Showed a significant difference for elite junior swimmers in Pull up $(\mathrm{P}=1.46)$, with a significant Correlation for 100 $\mathrm{m}$ freestyle $\left(\mathrm{r}=0.232\right.$ - $\left.^{*}\right)$.vertical jump $\left(\mathrm{P}=2.86^{* *}\right) \quad$ with a significant Correlation for 100 $\mathrm{m}$ freestyle $(\mathrm{r}=0.2675-*)$. Vertical jump score of athletes could be predicted by \%Fat which is related to the work performed during vertical jump (Davis DS, Briscope 2003). available test of $4 \times 50 \mathrm{~m} / 10$ $\sec \quad(\mathrm{P}=5.57 * *) \quad$ with a significant Correlation for 100 $\mathrm{m}$ freestyle $(\mathrm{r}=0.4583 * *) .400 \mathrm{~m}$ 
Run $\quad(\mathrm{P}=3.71 * *)$ with a significant Correlation $\left(\mathrm{r}=0.3275^{* *}\right) .10: 20 \quad$ Swim sprint $\quad\left(\mathrm{P}=3.10^{* *}\right)$ with a Correlation $(\mathrm{r}=0.4061 * *) \cdot 25: 50$ Swim sprint $(\mathrm{P}=7.78 * *)$ with a Correlation for $100 \mathrm{~m}$ freestyle $\left(\mathrm{r}=0.6045^{* *}\right)$. Grab/Track Start $15 \mathrm{~m}\left(\mathrm{P}=2.41^{*}\right)$ with a Correlation $(\mathrm{r}=0.3222 * *)$. Core Flexibility $(\mathrm{P}=4.12 * *)$ with a significant Correlation for 100 $\mathrm{m}$ freestyle $(\mathrm{r}=0.4343-* *)$. Core Flexibility $(\mathrm{P}=4.12 * *)$ with a significant Correlation $(\mathrm{r}=0.4343-* *)$. The core muscles are essential for swimmers because they use the whole body to transfer the forces. If there is lack of core stability the muscles can't transfer the force from the hands to the legs (Weston et al., 2015; Crowley, Harrison \& Lyons, 2017). Flexibility front Foot $(\mathrm{P}=2.74 * *) \quad$ and $\operatorname{Agility}\left(\mathrm{P}=2.15^{*}\right)$ for the elite swimmers. Body composition can affect strength and agility (Massuça \& Fragoso, 2011), whereas body mass can influence an athlete's speed, endurance, and power, it is well known that excessive fat mass compromises the physical performance (Nikolaidis \& Vassilios-Karydis, 2011), The main findings of the present study indicate that high level of body fat effects of fitness level for players(Halasi, S., \& Lepes, J. (2012). Also, it's no significant showed in other variables but its record high means numbers for elite junior swimmers than normal junior swimmers. Training power characteristics may become more important than training strength characteristics. Training at faster velocities during pull-ups may a critical factor in improving junior swimming performance. Also, Sprint and power during the upper and lower body testes important for successful sprint swimmer performance (PérezOlea et al). The relative and absolute strength in upper body correlated to both $50 \mathrm{~m}$ and $400 \mathrm{~m}$ freestyle and could therefore strengthen the importance of upper body strength in sprint and middle distance as previous researchers has stated. The upper body strength is the best predictor of time in $50 \mathrm{~m}$. The result in the current study showed in Table (3) the Contribution Ratio Characteristics for elite Swimmers effect in time of 100 
$m$ in next two ratio Total Contribution Ratio and Specific Contribution Ratio the first ratio Sprint $(S=1.037)$ with Total Contribution Ratio (TCR $=36 \%$ ), Specific Contribution Ratio ( $\mathrm{SCR}=36 \%)$.Second ratio Sprint $(S=0.789)$, Lead Body Mass (LBM=0.334) with Total Contribution Ratio (TCR=51\%), Specific Contribution

Ratio (SCR $=15 \%)$. Third ratio Sprint ( $\mathrm{S}=0.768)$, Lead Body Mass $(\mathrm{LBM}=0.307)$, Reaction time $(\mathrm{RT}=0.924) \quad$ with Total Contribution Ratio (TCR $=55 \%$ ), Specific Contribution Ratio (SCR=4\%). fourth ratio Sprint $(\mathrm{S}=0.705)$, Lead Body

Mass (LBM=0.268), Reaction time ( $\mathrm{RT}=0.902)$, Core Flexibility $(\mathrm{CF}=0.091) \quad$ with Total Contribution Ratio (TCR $=58 \%$ ), Specific Contribution Ratio (SCR=3\%). fifth ratio Sprint $(S=0.710)$, Lead Body Mass (LBM=0.180), Reaction time ( $\mathrm{RT}=0.921)$, Core Flexibility $(\mathrm{CF}=0.086)$, vital capacity $(\mathrm{VC}=0.001) \quad$ with Total Contribution Ratio (TCR=60\%), Specific Contribution Ratio (SCR=2\%). sixth ratio Sprint $(S=0.749)$, Lead Body Mass (LBM=0.156), Reaction time ( $\mathrm{RT}=1.037)$, Core Flexibility $(\mathrm{CF}=0.1292)$, vital capacity (VC=0.002), Shoulder Flexibility $(\mathrm{SF}=0.1001)$ with Total Contribution Ratio (TCR $=62 \%), \quad$ Specific Contribution Ratio $(\mathrm{SCR}=2 \%)$. When the swimmer gets fatigued the sense of where the shoulder is and proprioception is reduced. By implementing strength training mainly in the external rotators of the shoulder the proprioception in the humeral head develops and will in turn enhance the stroke length and rate (Matthews et al., 2017).

\section{Conclusion}

The physical testes and Body composition had a high correlation to the time in $100 \mathrm{~m}$ freestyle swim, which supports previous literature and underlines the importance body fitness and $100 \mathrm{~m}$ freestyle swim performance. Coaches must interest of anthropometrical and fitness testes for the junior swimmers. also recommend advanced research on individualized body composition analysis of both male and female junior 
and adult swimmers with differences in swimming techniques.

\section{References}

1- Body Composition

Tests. www.heart.org.

Retrieved 2015-11-25.

2- Composition of the body FREE composition of the body information

Encyclopedia.com: Find composition of the body research". www.encyclopedia.c om. Retrieved 2016-01-10.

3- Crowley, E., Harrison, A., \& Lyons, M. (2017). The Impact of Resistance Training on Swimming Performance: A Systematic Review. Sports Medicine, 47(11), 2285-2307.

4- Davis DS, Briscope DA, Markowski CT, Saville SE, Taylor CJ. Physical characteristics that predict vertical jump performance in recreational male athletes. Phys Ther Sport 2003; 4: 167-174.

5- Halasi, S., \& Lepes, J. (2012). The relations between body composition and motorical skills by the children of age 7. Sport Mont, X (3435-36), 89-93.

6- Hulmi, J.J.; Isola, V.; Suonpää, M.; Järvinen, N.J.; Kokkonen, M.; Wennerström, A.; Nyman,
K.; Perola, M.; Ahtiainen, J.P.; Häkkinen, K. The effects of intensive weight reduction on body composition and serum hormones in female fitness competitors. Front. Physiol. 2017, 7, 1-16. [CrossRef] [PubMed]

International Journal of Medical Science and Public Health | 2016 | Vol 5 | Issue 01 (Online First)

7- Khosla T JAMA Physique of female swimmers and divers from the 1976 Montreal Olympics. 1984 Jul 27; 252 (4): 536-7.

8- Krivokapic, D. (2007). The influence of different models of swimming training (defined in relation to anaerobic threshold) on the change of variables of body composition. Sport Mont, V (12-13-14), 158-166.

9- Krivokapic, D. (2007). The influence of different models of swimming training (defined in relation to anaerobic threshold) on the change of variables of body composition. Sport Mont, V (12-13-14), 158-166.

10- Malá, L.; Zahálka, F.; Maly, T. Bioimpedance for analysis of body composition in sport. In Bioimpedance in 
Biomedical Applications and Research; Simini, F., Bertemes-Filho, P., Eds.; Springer Nature Switzerland AG: Cham, Switzerland, 2017; pp. 243-256.

11- Masanovic, B. (2018). Comparative study of anthropometric measurement and body composition between junior basketball and volleyball players from Serbian national league. Sport Mont, 16(3), 1924. doi: $10.26773 /$ smj. 181004

13- Matthews, M. J., Green, D., Matthews, H., \& Swanwick, E. (2017). The effects of swimming fatigue on shoulder strength, range of motion, joint control, and performance in swimmers. Physical Therapy in Sport, 23, 118-122.

14- Massuca, L. \& Fragoso, I. (2011). Study of Portuguese handball players of different playing status.

A morphological and biosocial perspective. Biology of Sport, 28 (1), 37-44.

15- Matiegka, J. (1921). The testing of physical efficiency. American Journal of Physical Anthropology, 4, 223-30.

16- Mazzilli F. (2019). Body Height and Swimming Performance in 50 and $100 \mathrm{~m}$
Freestyle Olympic and World Championship Swimming Events: 1908 - 2016. Journal of human kinetics, 66, 205-213. doi:10.2478/hukin-2018-0068

17- McArdle, W.D.; Katch, F.I.; Katch, V.L. Body composition, energy balance, and weight control. In Exercise Physiology. Energy, Nutrition \& Human Performance; McArdlel, W.D., Katchl, F.I., Katchk, V.L., Eds.; Lippincott Williams \& Wilkins: Philadelphia, PA, USA, 2014; pp. 769-809.

18- Nikolaidis, P.T. \& Vassilios Karydis, N. (2011). Physique and body composition in soccer players across adolescence. Asian Journal of Sports Medicine, 2(2), 75-82.

19- Pallavi Dave, Rohit Subhedar, Priyanka Mishra, Dirgha Sharma. Body composition parameter changes among young male and female competitive swimmers and nonswimmers.

20- Pérez-Olea, J. I., Valenzuela, P. L., Aponte, C., \& Izquierdo, M. (2018). Relationship between dryland strength and swimming performance: Pull-up mechanics as a predictor of 
swimming speed. Journal of Strength and Conditioning Research, 1. doi: 10.1519/ JSC. 0000000000002037.

21- Shephard, M. E., Pritchard-Peschek, K. R., L., S. T., \& Bolam, K. A. (2014). Relationship between body composition and competition performance in swimming. XIIth International Symposium for Biomechanics and Medicine in Swimming, pp. 516-521.

22- Silvestre, R., Kraemer, W.J., West, C., Judelson, D.A., Spiering, B.A., Vingren, J.L., Hatfi eld, D.L., Anderson, J.M., \& Maresh, C.M. (2006). Body Composition and Physical Performance during a National Collegiate Athletic Association Division I Men's Soccer
Season. The Journal of Strength \& Conditioning Research, 20 (4), 962-70.

23- Subhedar R, Dave $P$, Mishra P, Mehta D. A study establishing the importance of individualized exercise prescription in physiotherapy for achieving physical fitness by comparative analysis of body composition, physical characteristics and physical activity. Int $\mathbf{J}$ Physiother 2015;2(1):317-26.

24- Weston, M., Hibbs, A. E., Thompson, K. G., \& Spears, I. R. (2015). Isolated core training improves sprint performance in national-level junior swimmers. International Journal of Sports Physiology and Performance, 10(2), 204210. 